This is the author's final, peer-reviewed manuscript as accepted for publication. The publisher-formatted version may be available through the publisher's web site or your institution's library.

\title{
Tolerance of foxtail, proso and pearl millets to saflufenacil
}

Seshadri S. Reddy, Phillip W. Stahlman, Patrick W. Geier, Leo D. Charvat, Robert G. Wilson, Michael J. Moechnig

\section{How to cite this manuscript}

If you make reference to this version of the manuscript, use the following information:

Reddy, S. S., Stahlman, P. W., Geier, P. W., Charvat, L. D., Wilson, R. G., \& Moechnig, M. J. (2014). Tolerance of foxtail, proso and pearl millets to saflufenacil. Retrieved from http://krex.ksu.edu

\section{Published Version Information}

Citation: Reddy, S. S., Stahlman, P. W., Geier, P. W., Charvat, L. D., Wilson, R. G., \& Moechnig, M. J. (2014). Tolerance of foxtail, proso and pearl millets to saflufenacil. Crop Protection, 57, 57-62.

Copyright: ( 2013 Elsevier Ltd.

Digital Object Identifier (DOI): doi:10.1016/j.cropro.2013.12.002

Publisher's Link: http://www.sciencedirect.com/science/article/pii/S0261219413003177

This item was retrieved from the K-State Research Exchange (K-REx), the institutional repository of Kansas State University. K-REx is available at http://krex.ksu.edu 


\section{Tolerance of Foxtail, Proso and Pearl Millets to Saflufenacil}

Seshadri S. Reddy ${ }^{1 *}$, Phillip W. Stahlman ${ }^{1}$, Patrick W. Geier ${ }^{1}$, Leo D. Charvat ${ }^{2}$, Robert G. Wilson ${ }^{3}$, Michael J. Moechnig ${ }^{4}$

${ }^{1}$ Agricultural Research Center, Kansas State University, $1232240^{\text {th }}$ Avenue, Hays, KS 67601, USA.

${ }^{2}$ BASF Corporation, 6211 Saddle Creek Trail, Lincoln, NE 68523, USA.

${ }^{3}$ University of Nebraska, 4502 Avenue I, Scottsbluff, NE 69361, USA.

${ }^{4}$ Plant Science Department, South Dakota State University, Brookings, SD 57007, USA.

*Corresponding author E-mail address: sajjala.reddy@gmail.com. 


\title{
Tolerance of Foxtail, Proso and Pearl Millets to Saflufenacil
}

\author{
Seshadri S. Reddy ${ }^{1}$, Phillip W. Stahlman ${ }^{1}$, Patrick W. Geier ${ }^{1}$, Leo D. Charvat ${ }^{2}$, \\ Robert G. Wilson ${ }^{3}$, Michael J. Moechnig ${ }^{4}$
}

\begin{abstract}
Herbicide options for weed control in millets are very limited and hence there is a need for exploring potential herbicides. Field trials were conducted at three locations in Kansas and Nebraska in 2009 to evaluate foxtail millet, proso millet, and pearl millet tolerance to saflufenacil applied preemergence (PRE) at 36, 50, and $100 \mathrm{~g}_{\text {aiha }}{ }^{-1}$. Foxtail millet wasthe most sensitive of the three millets to saflufenacil. Among experimental sites, saflufenacil at $36 \mathrm{~g} \mathrm{ha}^{-1}$ injured foxtail millet 59 to $99 \%$ and reduced plant stands 41 to $95 \%$; nearly all plants died at $100 \mathrm{~g} \mathrm{ha}^{-1}$. Despite early season foliar injury and up to $36 \%$ stand reduction, fodder or grain yields of proso and pearl millets were not reduced by any rate of saflufenacil compared to untreated controls. Additional trials were conductedat four locations in Kansas, Nebraska and South Dakota in 2010 and 2011 to refine saflufenacil use rate (36 and $50 \mathrm{~g} \mathrm{ha}^{-1}$ ) and application timing [14 days early preplant (EPP); 7 days preplant (PP); and PRE] for use in proso and pearl millets. Saflufenacil applied EPP or PP, regardless of rate, caused up to 21 and $6 \%$ foliar injury and up to 21 and 9\% plant stand reduction in proso and pearl millets, respectively. However, yields were not reduced by EPP or PP treatments in either milletcrop. PRE applications of saflufenacil caused the highest crop injury and stand reduction in both millets. Saflufenacil PRE at $36 \mathrm{~g} \mathrm{ha}^{-1}$ caused up to 57 and $40 \%$ foliar injury and up to 42 and $24 \%$ stand reductions in proso and pearl millets, respectively; however, yields were not affected. Comparatively, saflufenacil PRE at $50 \mathrm{~g} \mathrm{ha}^{-1}$ reduced yields of proso and pearl millets 36 and 52\%, respectively, on sandy loam soilswith high $\mathrm{pH}(8.3)$ and low organic matter content (1.1\%).Overall, results indicated that foxtail millet lacks tolerance to saflufenacil, but up to $50 \mathrm{~g} \mathrm{ha}^{-1}$ of saflufenacil maybe safely applied as near as 7 days before planting proso or pearl millets. If situation demands, saflufenacil at $36 \mathrm{~g} \mathrm{ha}^{-1}$ can also be applied PRE to either crop with risk of some crop injury. Key words: crop injury, herbicide, millets, preemergence, preplant, saflufenacil, weed management.
\end{abstract}




\section{Introduction}

Millet is a general term used for several small-seeded summer annual grass crops. Pearl millet (Pennisetum glaucum (L.) R. Br.), proso millet (Panicum miliaceumL.), and foxtail millet (Setaria italica L.) are the three millet types most commonly grown in the U.S. All three crops are well adapted to semiarid regions of the U.S. central Great Plains. Foxtail and pearl millets are primarily grown for forage and proso millet is primarily grown for grain, which is used in bird and livestock feed. Reasons for proso millet not being extensively used for forage are pubescence on leaves and stemsthat can cause irritation to livestock and lower leaf-to-stem ratio compared to other millets grown for forage. However, proso millet grain has higher feed value for livestock than corn or sorghum (Luis et al. 1982). Proso millet is often grown as a catch crop after main crop failure. It was planted on 137,000 ha in the U.S. in 2012 (USDA-NASS, 2013). Proso millet is produced mainly in Colorado, Nebraska and South Dakota, with Colorado typically producing over 50 percent of the U.S. crop. Unofficial estimated U.S. area planted to pearl millet for forage is 600,000 ha, whereascurrent statistics on planted hectares are not available for foxtail millet.

Weeds are the major production problem in millets (Hanna et al., 2004, Grabouski, 1971). Initial slow plant growth in millets, especially foxtail and proso millets, makes them susceptible to weed competition. Canada thistle [Cirsium arvense (L.) Scop.], kochia [Kochia scoparia(L.) Schrad.], redroot pigweed (Amaranthus retroflexus L.), green foxtail [Setaria viridis (L.) Beauv.], and Palmer amaranth (Amaranthus palmeri S. Watson) are among the most common troublesome weeds interfering with crops in the U.S. central Great Plains. Currently, few POST herbicides are registered for use in millets in the U.S.and atrazine no longer is registered for PRE use in millets. Flexibility with POST herbicides for effective weed control is less compared to preplant or PRE herbicides because POST herbicideshave to be applied only at early growth stages (2-5 leaf stage) of millets when weeds are only a few $\mathrm{cm}$ tall. Hence, there is a need for soil-applied herbicides with residual properties for use in millets.

Saflufenacil, a protoporphyrinogen IX oxidase (PPO)-inhibiting herbicide with both foliar and soil activity, belongs to the pyrimidinedione herbicide family (Grossman et al., 2010). Exposure of susceptible plants to saflufenacil results in bleaching of chloroplasts, tissue necrosis, growth 
reduction, and plant death. Saflufenacil was registered in the U.S. in 2010 for preplant burndown and preemegence control of many broadleaf weeds in several crops including corn, soybean, cotton, grain sorghum, and rice, and for crop desiccation (Grossmann et al. 2011).

Averaged across species in a greenhouse study, Geier et al.(2009) found that saflufenacil PRE at 6 to $30 \mathrm{~g}_{\text {aiha }}{ }^{-1}$ reduced the biomass of five broadleaf weeds including Palmer amaranth (Amaranthus palmeri S. Wats.), redroot pigweed (Amaranthus retroflexus L.) and tumble pigweed (Amaranthus albus L.) by 82 to $98 \%$ and by at least $92 \%$ when applied POST. Saflufenacil also controls other troublesome weeds such as common cocklebur (Xanthium strumarium L.), common lambsquarters (Chenopodium album L.), common ragweed (Ambrosia artemisiifolia L.), common waterhemp (Amaranthus rudis Sauer), giant ragweed (Ambrosia trifida L.), kochia [Kochia scoparia (L.) Schrad.], and velvetleaf (Abutilon theophrasti Medik.), including glyphosate, triazine and acetolactate synthase (ALS)-resistant biotypes (Anonymous 2008; Jenks et al. 2008, Liebl et al. 2008, Owen et al. 2011). Moreover, it is safe to many crops when applied PRE (Soltani et al. 2009, Soltani et al. 2010, Camargo et al. 2011). In Canada, saflufenacil PRE at 50 to100 $\mathrm{g} \mathrm{ha}^{-1}$ caused almost no visible injury and had no adverse effect on plant height or yield of spring small grains such as barley, oats, and wheat, but POST application of saflufenacil resulted in unacceptable crop injury and yield loss (Sikkema et al. 2008).

Little work has been reported on proso millet tolerance to saflufenacil and no literature is available on foxtail millet or pearl millet tolerance. Lyon and Kniss (2010) reported that saflufenacil, averaged across rates of 50 and $100 \mathrm{~g} \mathrm{ha}^{-1}$, reduced proso millet stand establishment by 23 and 33\% when applied 7 to 14 days PP and PRE, respectively; however, yields were not reduced. They concluded saflufenacil applied at a rate up to $100 \mathrm{~g} \mathrm{ha}^{-1} \mathrm{EPP}$ or $50 \mathrm{~g} \mathrm{ha}^{-1}$ PRE may be used safely in proso millet on soils with surface $\mathrm{pH}$ of $<7.8$.

The objectives of this study were 1) to compare the tolerance of foxtail, proso, and pearl millets to soil-applied saflufenacil and 2) to determine suitable use rates and application timings for each crop. 


\section{Materials and Methods}

\subsection{Year I}

Field trials were conducted in 2009 nearHays, Kansas (KS), Beaver Crossing, Nebraska (NE1), and Scottsbluff, Nebraska (NE2) in the central USA to evaluate the tolerance of foxtail millet, proso millet, and pearl millet to saflufenacil PRE at 36, 50 and $100 \mathrm{~g}$ aiha $^{-1}$. Soil characteristics, millet varieties, seeding rates and dates, plot sizes, andherbicide application dates for each experimental site are shown in Table 1. Experimental design for each crop was a randomized complete block with four treatment replications. Crop row spacing was $30 \mathrm{~cm}$ at KS, $20 \mathrm{~cm}$ at NE1 and NE2, and $15 \mathrm{~cm}$ at SD. Herbicides were applied in water immediately after planting using $\mathrm{CO}_{2}$-powered backpack or tractor-mounted plot sprayers calibrated to deliver 140 to 187 $\mathrm{L} \mathrm{ha}^{-1}$ at spray pressures of 221 to $276 \mathrm{kPa}$. A non-treated control for all three millets was included at each site.

Crop response wasrated visually 14 days after planting (DAP) based on composite visual estimations of foliar injury, growth inhibition and density reduction on a scale of 0 (no injury) to 100 (death ). Plant stand reductions were assessed 18, 25 and 49 DAP at KS, NE1 and NE2, respectively. Percentage stand reductions compared to untreated controls were determined by taking plant counts $\mathrm{m}^{-2}$ in two quadrants in each plot at the KS and NE2 sites and by visual estimation at NE1. Fresh fodder yields of all three millets were determined 55 and 79 DAP at NE1 and NE2 sites, respectively. At KS, fresh fodder yields of foxtail and pearl millets were determined 66 DAP and grain yields of proso millet were determined at maturity. Grain yields of proso millet were adjusted to $14 \%$ moisture. Weed control was not assessed.

\subsection{Years II and III}

Field experiments were conducted in 2010 and 2011 atthe same three locations as in Year I (KS, NE1 and NE2) and a fourth location near Brookings, South Dakota (SD) to evaluate the effects of saflufenacil application timing on proso millet and pearl millet tolerance to the herbicide. Soil characteristics of experimental sites, crop and herbicide application information are shown in Table 1. Treatments include two rates of saflufenacil ( 36 and $50 \mathrm{~g} \mathrm{ha}^{-1}$ ) and three application timings (14 days EPP; 7 days PP; and PRE). In 2010, PP treatments at the NE2 site and EPP treatments at the SD site were not tested. A non-treated control for both crops was 
included at each site in both years. Experimental design was the same as in Year I. Weed control was not assessed.

Herbicide applications and crop assessments were performed the same as described in Year I. Plant stand reductions were determined 26, 13 and 19 DAP at KS, NE1 and NE2, respectively, in 2010 and 14 and 26 DAP at KS and NE2, respectively, in 2011. Plant stand reduction was not determined at the SD site in either year. Fresh fodder yields of proso and pearl millets at each sitewere determined 48 to 90 DAP in 2010, and 68 to 81 DAP at KS, NE2 and SD sites in 2011. Grain yields of proso millet, adjusted to $14 \%$ moisture, were determined at maturity at KS in 2010 and at KS and NE2 in 2011.

Data were analyzed using the general linear model procedure of the Statistical Analysis System (Statistical Analysis Systems Institute, Cary, NC, USA) and means were separated at the 5\% significance level using Fisher's protected LSD. Crop injury percentages were arcsine transformed before analysis, but original values are presented in this paper. The control treatment was omitted from crop injury and stand reduction analyses, but included in analyses of fodder and grain yields. Data are presented by year or experimental site when significant ( $P$ $\leq 0.05$ ) year and or site interactions occurred. In addition, linear regression analyses were done to test the relation between saflufenacil rates and millet injury and yields in 2009.

$y=a+b x$

Where $y$ is an estimation of crop injury or yield, $x$ is saflufenacil rate, $a$ is the intercept and $b$ is the slope.

\section{Results and Discussion}

\subsection{Year I}

Rainfall (KS and NE1) or rainfall plus sprinkler irrigation (NE2) within 7 days after treatment (DAT) totalled $36 \mathrm{~mm}$ at KS, $18 \mathrm{~mm}$ at NE1 and $24 \mathrm{~mm}$ at NE2. Response of each millet type to saflufenacil varied considerably among sites. Foxtail millet was severely injured by saflufenacil PRE at all sites at 14 DAP (Table 2). Saflufenacil at $36 \mathrm{~g} \mathrm{ha}^{-1}$ injured foxtail millet 70, 59 , and $99 \%$ at KS, NE1, and NE2, respectively. Saflufenacil at 50 and $100 \mathrm{~g} \mathrm{ha}^{-1}$ increased crop injury by 14 and 25 percentage points at KS and 19 and 40 percentage points at NE1, respectively, compared to the $36 \mathrm{~g} \mathrm{ha}^{-1}$ rate. At NE2, all saflufenacil rates caused $99 \%$ injury. 
Proso millet and pearl millet exhibited considerably greater tolerance to saflufenacil than foxtail millet at all sites (Fig. 1). Across sites, saflufenacil at $36 \mathrm{~g} \mathrm{ha}^{-1}$ injured proso millet 10 to $25 \%$ and pearlmillet 11 to $19 \%$ at 14 DAP. Least-square linear regression analysis indicated a strong positive relationship $\left(R^{2}=0.94\right.$ or more) between saflufenacil rate and injury of both millets in all sites (Fig 1). Highest slope values were observed at NE2 location for proso and pearl millets ( 0.83 and 0.84 , respectively). Compared to $36 \mathrm{~g} \mathrm{ha}^{-1}$ rate, the $50 \mathrm{~g} \mathrm{ha}^{-1}$ rate increased proso millet injury at KS from 11 to $20 \%$ and at NE1 from 10 to $25 \%$. Further increasing saflufenacil rate from 50 to $100 \mathrm{~g} \mathrm{ha}^{-1}$ resulted in 40,69, and 83\% injury at KS, NE1 and NE2, respectively. Similarly, pearl millet injury increased to 18,35 and $25 \%$ with $50 \mathrm{~g} \mathrm{ha}^{-1}$ rate and 28 , 61 and $83 \%$ with $100 \mathrm{~g} \mathrm{ha}^{-1}$ rate at KS, NE1 and NE2 locations respectively. Analysis indicated that there was significant difference between KS and NE2 regression slopes for proso millet injury $(P<0.05)$, but there was no significant difference between NE1 and NE2; and KS and NE1 slopes. Also, there were significant differences between KS and NE1; and KS and NE2 slopes for pearl millet injury.

Plant stand reduction also was greatest in foxtail millet due to saflufenacil compared to the other two millets (Table 2 and 3). Among sites, saflufenacil at $36 \mathrm{~g} \mathrm{ha}^{-1}$ PRE reduced foxtail millet stand by 41 to $95 \%$ compared to untreated controls. Plant stands were further reduced with increased saflufenacil rate; $\geq 88 \%$ stand loss with $100 \mathrm{~g} \mathrm{ha}^{-1}$ of saflufenacil at all sites. In comparison, plant stand reductions in proso and pearl millets among sites were as much as 8 and $13 \%$, respectively, due to saflufenacil at $36 \mathrm{~g} \mathrm{ha}^{-1}$ and as much as $36 \%$ stand loss at $100 \mathrm{~g} \mathrm{ha}^{-}$ 1.

Fodder yields (wet weight) of foxtail millet varied greatly among sites (Fig. 2). Linear regression analysis indicated a strong negative relation $\left(R^{2}=0.92\right.$ or more) between saflufenacil rate and fodder yields of foxtail millet. The slope values were 221, 239 and $79 \mathrm{~kg} \mathrm{ha}^{-1}$ of fodder yield per gram of saflufenacil at KS, NE1 and NE2, respectively. As evidenced from figure 2, analysis indicated that there was no significant difference between KS and NE1 regression slopes. Saflufenacil at $36 \mathrm{~g} \mathrm{ha}^{-1}$ reduced fodder yields of foxtail millet by 30 and $50 \%$ at the KS and NE2 sites, respectively, compared to untreated controls. Fodder yield losses across sites ranged from 29 to $75 \%$ and 74 to $100 \%$ with 50 and $100 \mathrm{~g} \mathrm{ha}^{-1}$ rates, respectively. 
Unlike foxtail millet, fodder yields of pearl and proso millets were not reduced by any rate of saflufenacil at any site despite significant stand losses at the $100 \mathrm{~g} \mathrm{ha}^{-1}$ rate in both crops (Table 3). Furthermore, at the KS site, proso millet grain yields were higher for all saflufenacil treatments compared to the untreated control, presumably because of high Southwestern cupgrass [Eriochloa gracilis (Fourn.) A.S. Hitch.] density and good control at this site (control data not shown). Grain yield was higher at the $36 \mathrm{~g} \mathrm{ha}^{-1}$ rate than the 50 or $100 \mathrm{~g} \mathrm{ha}^{-1}$ rates.

Results of these experiments indicated that foxtail millet was the most sensitive to saflufenacil of the three millets tested. Foxtail millet was essentially killed ( $\geq 95 \%$ injury and $>85 \%$ stand reduction) by saflufenacil at $100 \mathrm{~g} \mathrm{ha}^{-1}$. Despite early season injury and stand reductions, there was no yield reduction in proso or pearl millets treated with saflufenacil PRE up to $100 \mathrm{~g} \mathrm{ha}^{-1}$. These results indicated that saflufenacil has potential for use in proso and pearl millets, but additional studies were needed to refine use rates and evaluate the effects of preplant application timings on crop safety.

\subsection{Years II and III}

Saflufenacil at 36 or $50 \mathrm{~g} \mathrm{ha}^{-1}$ caused $\leq 6 \%$ foliar injury to proso millet at 3 of 4 sites (Table 4 ) and $\leq 6 \%$ injury to pearl millet at all sites when applied EPP or PP (Table 5). Those treatments injured proso millet 17 to $21 \%$ at the KS site, where in both years $20 \mathrm{~mm}$ to as much as $54 \mathrm{~mm}$ rainfall and/or sprinkler irrigation was received within four days after each application. In most instances injury to both proso and pearl millets was greatest when saflufenacil was applied PRE, especially at the NE2 site in 2011, which received $\sim 30 \mathrm{~mm}$ rainfall and irrigation prior to crop emergence. Abundant rainfall and/or irrigation soon after herbicide applications coupled with coarse soil texture at NE2 and high soil pH ( $\geq 8.0)$ and low organic matter content (1.1-1.6\%) at both KS and NE2 sites likely explain the greater crop injury observed at those sites compared to the NE1 and SD sites. Plants of both proso millet and pearl millet not killed by saflufenacil recovered within 3 to 4 weeks and grew normally.

Proso millet and pearl millet plant stands were not reduced by any saflufenacil treatment at the KS site in either year or at the NE2 site in 2010 (Tables 6 \& 7). At NE1 in 2011, proso millet stand was not reduced by saflufenacil treatments, but pearl millet stand was reduced $23-24 \%$ with PRE treatments. Conversely, at NE2 in 2011 saflufenacil PRE reduced proso millet stand 50 
$\pm 8 \%$ and caused up to $30 \%$ pearl millet stand loss; however, the latter was not significant. In no instance did stand loss differ between saflufenacil rates. The foliar injury and stand loss caused by saflufenacil PRE treatments at NE2 in 2011 was reflected in 36 and 52\% lower proso and pearl millets fodder yields, respectively, compared to untreated controls (data not shown). Crop yields in other sites were not negatively affected despite early season injury or stand loss.

Among experimental sites, the magnitude of overall crop injury due to saflufenacil application was highest at NE2. This site had higher soil pH (7.9 to 8.3) and lower organic matter (OM) content $(\leq 1.1 \%)$ than the other sites. Saflufenacil has a water solubility of $30 \mathrm{mg} \mathrm{L}^{-}$ ${ }^{1}$ at $\mathrm{pH} \mathrm{5.0,} \mathrm{and} 2100 \mathrm{mg} \mathrm{L}^{-1}$ at $\mathrm{pH} 7$ (Anonymous, 2008), which means increased saflufenacil bioactivity with increased soil pH. Bioactivity of many herbicides is inversely correlated with the OMcontent of the soil as the sorption of herbicides increase with increased soil OM (Grover 1966; Parochetti 1973; Weber et al. 1974). This explains the reason behind higher crop injury at the NE2 site. Lyon and Kniss (2010) also reported increased proso millet injury with saflufenacil in soils with high $\mathrm{pH}$ and low organic matter.

This study found that foxtail millet is considerably more susceptible to soil-applied saflufenacil than proso millet or pearl millet. Saflufenacil PRE at rates as low as $36 \mathrm{~g} \mathrm{ha}^{-1}$ reduced foxtail millet stand establishment and fodder yield. These negative crop effects were magnified on coarse-textured soils with high $\mathrm{pH}$ and low organic matter content. We conclude the risk of crop injury is too high to consider registering saflufenacil for use in foxtail millet.

Minor crop response $(<10 \%)$ was observed in proso millet and pearl millet grown on soils with $\mathrm{pH}<7$ and greater than $2 \%$ organic matter content when saflufenacil was applied 7 or 14 days preplant. Greater crop response occurred with preplant treatments on high $\mathrm{pH}(\geq 8.0)$ and low organic matter $(\leq 1.6 \%)$ soils but injured plants recovered in 3 to 4 weeks, grew normally, and yields were not reduced compared to non-treated controls. In comparison, PRE-applied saflufenacil caused considerably higher crop injury and plant stand reductions than preplant applications in all but the SD site in 2011, where no injury was observed. As with preplant applications, greatest injury was at sites with high soil pH and low organic matter content. When these characteristics were coupled with coarse soil texture and rainfall prior to crop emergence, significant yield losses resulted in both crops. 
We further conclude that saflufenacil up to $50 \mathrm{~g}$ aiha ${ }^{-1}$ can safely be applied 7 or more days preplant to proso or pearl millets on medium- or fine-textured soils with neutral or acidic $\mathrm{pH}$ and greater than $2 \%$ organic matter content. If it is necessary to apply saflufenacil PRE, rate should not exceed $36 \mathrm{~g} \mathrm{ha}^{-1}$; some early season crop injury may occur.

\section{Acknowledgements}

The authors thank BASF Corporation for their financial support of this project. Contribution number 14-181-J from the Kansas Agricultural Experiment Station. 


\section{References}

Anonymous. 2008. Kixor ${ }^{\circledR}$ Herbicide Worldwide Technical Brochure. BASF Publication No.GL69288. Research Triangle Park, NCBASF Corporation. 18.

Camargo, E.R., Senseman, S.A., McCauley, G.N., Guice, J.B., 2011. Rice tolerance to saflufenacil in clomazoneweed control program.Int. J. Agron.Online.doi:10.1155/2011/402461.

Geier, P.W., Stahlman, P.W. and Charvat, L.D., 2009. Dose response of five broadleaf weeds tosaflufenacil. Weed Technol. 23, 313-316.

Grabouski, P.H., 1971. Selective control of weeds in proso millet with herbicides. Weed Sci. 19, 207-209.

Grossmann, K., Hutzler, J., Caspar, G., Kwiatkowski, J., Brommer, C.L., 2011. Saflufenacil $\left(\right.$ Kixor $\left.^{\mathrm{TM}}\right)$ : Biokinetic properties and mechanism of selectivity of a new protoporphyrinogen IX oxidase inhibiting herbicide. Weed Sci. 59, 290-298.

Grossmann, K., Niggeweg, R., Christiansen, N., Looser, R., and Ehrhardt, T., 2010. The herbicide saflufenacil (Kixor ${ }^{T M}$ ) is a new inhibitor of protoporphyrinogen IX oxidase activity. Weed Sci. 58, 1-9.

Grover, R., 1966. Influence of organic matter, texture and available water on the toxicity of simazine in soil. Weeds 14, 148-151.

Hanna, W.W., Baltensperger, D.D., Seetharam, A., 2004. Pearl millet andother millets.Pages 537-560 in L. E. Moser, et al. (2004). AgronomyMonographs 45: Warm-Season (C4) Grasses. Madison, WI: American Societyof Agronomy.

Jenks, B.M., Ball, D.A., Stahlman, P.W., Frihauf, J.C., 2008. Preplant weed control and wheat tolerance to BAS $800 \mathrm{H}$. Proc. West. Soc. Weed Sci. 61, 55.

Liebl, R.A., Walter,H., Bowe, S.J., Holt, T.J., Westberg, D.E.,2008. BAS 800H: a new herbicide for preplantburndown and preemergence dicot weed control.Weed Sci. Soc. Am. 48, 120.

Luis, E.S., Sullivan, T.W., Nelson, L.A., 1982. Nutrient composition and feeding value of proso millets, sorghum grains and corn in broiler diets. Poultry Sci. 6, 311-320.

Lyon, D.J., Kniss, A.R., 2010. Proso millet tolerance to saflufenacil. Weed Technol. 24, 349-355.

Owen, L.N., Mueller, T.C.,Main,C.L., Bond, J., Steckel, L.E., 2011.Evaluating rates and application timings of saflufenacil for control of glyphosate-resistant horseweed (Conyza canadensis) prior to planting no-till cotton. Weed Technol.25, 1-5.

Parochetti, J.V., 1973. Soil organic matter effect on activity of acetamides, CDAA, and atrazine. Weed Sci. 21, 157-160.

Sikkema, P.H., Soltani, N., and Shropshire, C., 2008. Tolerance of spring barley (Hordeumvulgare L.), oats (Avena Sativa L.) and wheat (Triticum aestivum L.) to saflufenacil. Crop Prot. 27, 1495-1497.

Soltani, N., Shropshire,C., Sikkema, P.H., 2009. Response of corn to preemergence and postemergence applications of saflufenacil. Weed Technol. 23, 331-334. 
Soltani, N., Shropshire, C., Sikkema, P.H., 2010. Sensitivity of leguminous crops to saflufenacil. Weed Technol. 24, 143-146.

USDA-NASS. 2013. Quick stats: Agricultural statistics database. Available at: http://www.nass.usda.gov/QuickStats/.Accessed November 09, 2013.

Weber, J.B., Monaco, T.J., Carringer, R.D., Eaddy, D.W., 1974. Effect of organic matter and volume weight of North Carolina soils on herbicide performance. Proc. South. Weed Sci. Soc. $27,371-377$. 
Table 1.Soil characteristics and experimental details, 2009-2011 .

\begin{tabular}{|c|c|c|c|c|c|c|c|c|c|c|c|c|}
\hline \multirow[b]{3}{*}{ Soil type } & & \multicolumn{3}{|c|}{$\mathrm{KS}$} & \multicolumn{3}{|c|}{ NE1 } & \multicolumn{3}{|c|}{ NE2 } & \multicolumn{2}{|c|}{ SD } \\
\hline & & 2009 & 2010 & 2011 & 2009 & 2010 & 2011 & 2009 & 2010 & 2011 & 2010 & 2011 \\
\hline & & Silt loam & Silt loam & Silt loam & Silt loam & $\begin{array}{c}\text { Silt } \\
\text { loam }\end{array}$ & $\begin{array}{c}\text { Silt } \\
\text { loam }\end{array}$ & Sandy loam & $\begin{array}{l}\text { Sandy } \\
\text { loam }\end{array}$ & $\begin{array}{l}\text { Sandy } \\
\text { loam }\end{array}$ & $\begin{array}{l}\text { Clay } \\
\text { loam }\end{array}$ & $\begin{array}{l}\text { Clay } \\
\text { loam }\end{array}$ \\
\hline $\mathrm{pH}$ & & 7.8 & 8.1 & 8.0 & 4.7 & 5.2 & 6.7 & 8.1 & 7.9 & 8.3 & 6.2 & 6.4 \\
\hline OM (\%) & & 1.5 & 1.6 & 1.5 & 3 & 2.5 & 2.2 & 1 & 1.1 & 1.1 & 3.2 & 3.0 \\
\hline $\begin{array}{l}\text { Date of } \\
\text { planting }\end{array}$ & & June 8 & June 16 & June 17 & June 05 & June 18 & May 24 & June 22 & July 09 & June 23 & July 13 & June 16 \\
\hline $\begin{array}{l}\text { Plot size } \\
(\mathrm{m})\end{array}$ & & $1.8 \times 6$ & $1.8 \times 6$ & $1.8 \times 6$ & $4.5 \times 8$ & $3 \times 8$ & $3 \times 8$ & $3.4 \times 11$ & $3.4 \times 7.3$ & $3.4 \times 7.3$ & $3 \times 9$ & $3 \times 9$ \\
\hline \multirow{3}{*}{$\begin{array}{l}\text { Date of } \\
\text { spraying }\end{array}$} & EPP & $-b$ & June 05 & June 03 & - & June 04 & May 10 & - & June 25 & June 08 & - & June 01 \\
\hline & PP & - & June 12 & June 10 & - & June 11 & May 16 & - & - & June 15 & July 06 & June 09 \\
\hline & PRE & June 8 & June 16 & June 17 & June 05 & June 18 & May 24 & June 22 & July 09 & June 24 & July 13 & June 16 \\
\hline \multirow{2}{*}{$\begin{array}{l}\text { Foxtail } \\
\text { millet }\end{array}$} & $\begin{array}{l}\text { Variety } \\
\text { Seed rate }\end{array}$ & $\begin{array}{l}\text { German } \\
\text { Strain R }\end{array}$ & $-c$ & - & $\begin{array}{l}\text { German } \\
\text { Strain R }\end{array}$ & - & - & $\begin{array}{l}\text { Golden } \\
\text { German }\end{array}$ & - & - & - & - \\
\hline & $\left(\mathrm{kg} \mathrm{ha}^{-1}\right)$ & 20 & - & - & 17 & - & - & 21 & - & - & - & - \\
\hline \multirow{2}{*}{$\begin{array}{l}\text { Pearl } \\
\text { millet }\end{array}$} & Variety & Elite II & Elite II & Elite II & Elite II & Elite II & Elite II & TIFF III & Elite II & Elite II & Elite II & Elite II \\
\hline & $\left(\mathrm{kg} \mathrm{ha}^{-1}\right)$ & 19 & 19 & 17 & 22 & 27 & 17 & 21 & 21 & 21 & 20 & 20 \\
\hline \multirow{2}{*}{$\begin{array}{l}\text { Proso } \\
\text { millet }\end{array}$} & & Sunrise & $\begin{array}{l}\text { Early } \\
\text { Bird }\end{array}$ & $\begin{array}{l}\text { Early } \\
\text { Bird }\end{array}$ & Sunrise & $\begin{array}{l}\text { Early } \\
\text { Bird }\end{array}$ & $\begin{array}{l}\text { Early } \\
\text { Bird }\end{array}$ & $\begin{array}{l}\text { Early } \\
\text { White }\end{array}$ & $\begin{array}{l}\text { Early } \\
\text { Bird }\end{array}$ & $\begin{array}{l}\text { Early } \\
\text { Bird }\end{array}$ & $\begin{array}{l}\text { Early } \\
\text { Bird }\end{array}$ & $\begin{array}{l}\text { Early } \\
\text { Bird }\end{array}$ \\
\hline & $\begin{array}{l}\text { Seed rate } \\
\left(\mathrm{kg} \mathrm{ha}^{-1}\right)\end{array}$ & 21 & 22 & 21 & 28 & 27 & 27 & 21 & 21 & 21 & 20 & 20 \\
\hline
\end{tabular}

2 abbreviations: EPP, early preplant; PP, preplant; PRE, preemergence; KS, Hays, KS; NE1, Beaver Crossing, NE; NE2, Scottsbluff, NE;

3 SD, Brookings, SD.

$4{ }^{\mathrm{b}}$ Treatment was not tested.

$5 \quad{ }^{\mathrm{c}}$ Foxtail millet was not tested. 
6 Table 2. Foxtail millet response to saflufenacil PRE at 14 days after treatment at Hays, KS,

7 Beaver Crossing, NE, and Scottsbluff, NE, 2009 .

\begin{tabular}{crrr|rrr}
\hline \multirow{2}{*}{$\begin{array}{c}\text { Saflufenacil } \\
\text { rate }\end{array}$} & KS & NE1 & NE2 & KS & NE1 & NE2 \\
\cline { 1 - 5 } g ha $^{-1}$ & & & & & \multicolumn{3}{c}{ Stand reduction } \\
0 & $-{ }^{\mathrm{b}}$ & - & - & - & - & - \\
36 & 70 & 59 & 99 & 76 & 41 & 95 \\
50 & 84 & 78 & 99 & 81 & 58 & 98 \\
100 & 95 & 99 & 99 & 88 & 90 & 100 \\
LSD (0.05) & 4 & 12 & NS & 9 & 14 & 3 \\
\end{tabular}

8 a Abbreviations: KS, Hays, KS; NE1, Beaver Crossing, NE; NE2, Scottsbluff, NE.

9 bero values for non-treated controls were omitted from analyses of percentage data.

10

11

12

13

14

15

16

17

18

19

20

21

22 
23 Table 3. Proso millet and pearl millet response to saflufenacil PRE at 14 days after treatment at

24 Hays, KS, Beaver Crossing, NE, and Scottsbluff, NE, 2009ª.

25

26

\begin{tabular}{|c|c|c|c|c|c|c|}
\hline \multirow{2}{*}{$\begin{array}{c}\text { Saflufenacil } \\
\text { rate }\end{array}$} & \multicolumn{3}{|c|}{ Stand reduction } & \multicolumn{3}{|c|}{ Fodder/grain yields } \\
\hline & KS & NE1 & NE2 & $\mathrm{KS}^{\mathrm{b}}$ & NE1 & NE2 \\
\hline \multirow[t]{2}{*}{$\mathrm{g} \mathrm{ha}^{-1}$} & 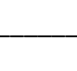 & $-\%$ & - & 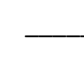 & t ha ${ }^{-1}$ & - \\
\hline & & & & & & \\
\hline 0 & $-^{c}$ & - & - & 3.1 & 19 & 25 \\
\hline 36 & 0 & 0 & 8 & 3.6 & 17 & 23 \\
\hline 50 & 11 & 3 & 11 & 3.4 & 15 & 23 \\
\hline 100 & 7 & 13 & 36 & 3.3 & 14 & 22 \\
\hline \multirow[t]{2}{*}{ LSD (0.05) } & NS & 5 & 16 & 0.2 & NS & NS \\
\hline & & - & Pea & illet- & & ----- \\
\hline 0 & - & - & - & 44 & 38 & 58 \\
\hline 36 & 13 & 0 & 7 & 47 & 40 & 62 \\
\hline 50 & 21 & 0 & 22 & 47 & 38 & 53 \\
\hline 100 & 25 & 10 & 36 & 47 & 37 & 42 \\
\hline LSD (0.05) & NS & 0 & NS & NS & NS & NS \\
\hline
\end{tabular}

27 abbreviations: KS,Hays, KS; NE1, Beaver Crossing, NE; NE2, Scottsbluff, NE.

$28{ }^{b}$ Values for proso millet at the KS site are grain yields; all other values are fodder yields.

29 'Zero values for non-treated controls were omitted from analyses of percentage data

30

31

32

33

34

35 
36 Table 4. Proso millet injury 14 days after planting as affected by saflufenacil use rate and

37 application timing at four experimental sites, 2010 and $2011^{\text {a }}$.

\begin{tabular}{|c|c|c|c|c|c|c|c|}
\hline \multirow{2}{*}{$\begin{array}{l}\text { Time of } \\
\text { application }\end{array}$} & \multirow{2}{*}{$\begin{array}{c}\text { Saflufenacil } \\
\text { rate }\end{array}$} & \multirow{2}{*}{$\begin{array}{c}\text { KS } \\
\text { Pooled }^{\text {b }}\end{array}$} & \multirow{2}{*}{$\begin{array}{c}\text { NE1 } \\
\text { Pooled }\end{array}$} & \multicolumn{2}{|c|}{ NE2 } & \multicolumn{2}{|c|}{ SD } \\
\hline & & & & 2010 & 2011 & 2010 & 2011 \\
\hline & $\mathrm{g} \mathrm{ha}^{-1}$ & & & 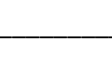 & $\%$ & & 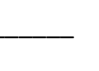 \\
\hline Early preplant & 36 & 19 & 1 & 3 & 0 & $-{ }^{c}$ & 1 \\
\hline Early preplant & 50 & 17 & 1 & 3 & 0 & - & 0 \\
\hline Preplant & 36 & 20 & 5 & - & 2 & 0 & 1 \\
\hline Preplant & 50 & 21 & 3 & - & 5 & 0 & 6 \\
\hline Preemergence & 36 & 25 & 16 & 15 & 57 & 5 & 4 \\
\hline Preemergence & 50 & 32 & 18 & 15 & 72 & 10 & 8 \\
\hline LSD (0.05) & & 14 & 7 & 8 & 26 & 7 & 4 \\
\hline
\end{tabular}

38 a Abbreviations: KS,Hays, KS; NE1, Beaver crossing, NE; NE2, Scottsbluff, NE.

$39 \quad{ }^{\mathrm{b}}$ Means averaged over years.

40 'Treatment not applied.

41

42

43

44

45

46

47

48

49

50

51

52

53

54

55

56

57

58 
59 Table 5. Pearl millet injury 14 days after planting as affected by saflufenacil use rate and 60 application timing at four experimental sites, 2010 and $2011^{\mathrm{a}}$.

\begin{tabular}{|c|c|c|c|c|c|c|c|}
\hline \multirow{2}{*}{$\begin{array}{l}\text { Time of } \\
\text { application }\end{array}$} & \multirow{2}{*}{$\begin{array}{c}\text { Saflufenacil } \\
\text { rate }\end{array}$} & \multirow{2}{*}{$\begin{array}{c}\text { KS } \\
\text { Pooled }^{\mathrm{b}}\end{array}$} & \multirow{2}{*}{$\begin{array}{c}\text { NE1 } \\
\text { Pooled }\end{array}$} & \multicolumn{2}{|c|}{ NE2 } & \multicolumn{2}{|c|}{ SD } \\
\hline & & & & 2010 & 2011 & 2010 & 2011 \\
\hline & $\mathrm{g} \mathrm{ha}^{-1}$ & & & . & $\%$ & & - \\
\hline Early preplant & 36 & 1 & 2 & 0 & 0 & $-^{c}$ & 0 \\
\hline Early preplant & 50 & 4 & 2 & 0 & 0 & - & 0 \\
\hline Preplant & 36 & 4 & 5 & - & 2 & 0 & 0 \\
\hline Preplant & 50 & 6 & 3 & - & 5 & 1 & 0 \\
\hline Preemergence & 36 & 6 & 14 & 16 & 40 & 8 & 0 \\
\hline Preemergence & 50 & 12 & 17 & 21 & 58 & 6 & 0 \\
\hline LSD (0.05) & & 7 & 7 & 4 & 15 & 3 & NS \\
\hline
\end{tabular}

61 a Abbreviations: KS,Hays, KS; NE1, Beaver crossing, NE; NE2, Scottsbluff, NE.

$62{ }^{\mathrm{b}}$ Means averaged over years.

63 'Treatment not applied.

64

65

66

67

68

69

70

71

72

73

74

75

76

77 
78 Table 6. Proso millet plant stand reduction as affected by saflufenacil use rate and application

79 timing at three experimental sites, 2010 and $2011^{\mathrm{a}}$.

\begin{tabular}{lccccc}
\hline \multirow{2}{*}{$\begin{array}{l}\text { Time of } \\
\text { application }\end{array}$} & $\begin{array}{c}\text { Saflufenacil } \\
\text { rate }\end{array}$ & $\begin{array}{c}\text { KS } \\
\text { Pooled }^{\text {b }}\end{array}$ & $\begin{array}{c}\text { NE1 } \\
2010\end{array}$ & 2010 & 2011 \\
\cline { 5 - 6 } g ha $^{-1}$ & 36 & 4 & 0 & c $^{c}$ & 21 \\
Early preplant & 50 & 4 & 0 & - & 13 \\
Early preplant & 36 & 0 & 1 & 5 & 14 \\
Preplant & 50 & 1 & 0 & 0 & 20 \\
Preplant & 36 & 4 & 6 & 9 & 42 \\
Preemergence & 50 & 14 & 7 & 4 & 58 \\
Preemergence & & NS & NS & NS & 22 \\
\hline LSD (0.05) & & & & & 9 \\
\hline
\end{tabular}

80 a Abbreviations: KS,Hays, KS; NE1, Beaver crossing, NE; NE2, Scottsbluff, NE.

$81{ }^{b}$ Means averaged over years.

$82{ }^{\mathrm{C}}$ Treatment not applied.

83

84

85

86

87

88

89

90

91

92

93

94

95

96 
97 Table 7. Pearl millet plant stand reduction as affected by saflufenacil use rate and application 98 timing at three experimental sites, 2010 and $2011^{\mathrm{a}}$.

\begin{tabular}{|c|c|c|c|c|c|}
\hline \multirow{2}{*}{$\begin{array}{l}\text { Time of } \\
\text { application }\end{array}$} & \multirow{2}{*}{$\begin{array}{c}\text { Saflufenacil } \\
\text { rate }\end{array}$} & \multirow{2}{*}{$\begin{array}{c}\text { KS } \\
\text { Pooled }^{\text {b }}\end{array}$} & \multirow{2}{*}{$\begin{array}{l}\text { NE1 } \\
2010 \\
\end{array}$} & \multicolumn{2}{|c|}{ NE2 } \\
\hline & & & & 2010 & 2011 \\
\hline & $\mathrm{g} \mathrm{ha}^{-1}$ & & 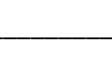 & & 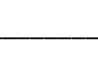 \\
\hline Early preplant & 36 & 4 & 0 & $-c$ & 8 \\
\hline Early preplant & 50 & 1 & 0 & - & 0 \\
\hline Preplant & 36 & 6 & 6 & 1 & 0 \\
\hline Preplant & 50 & 8 & 0 & 9 & 0 \\
\hline Preemergence & 36 & 4 & 24 & 17 & 11 \\
\hline Preemergence & 50 & 8 & 23 & 14 & 30 \\
\hline LSD (0.05) & & NS & 17 & NS & NS \\
\hline
\end{tabular}

99 abbreviations: KS,Hays, KS; NE1, Beaver crossing, NE; NE2, Scottsbluff, NE.

$100{ }^{b}$ Means averaged over years.

101 'Treatment not applied.

102

103

104

105

106

107

108

109

110

111

112

113 


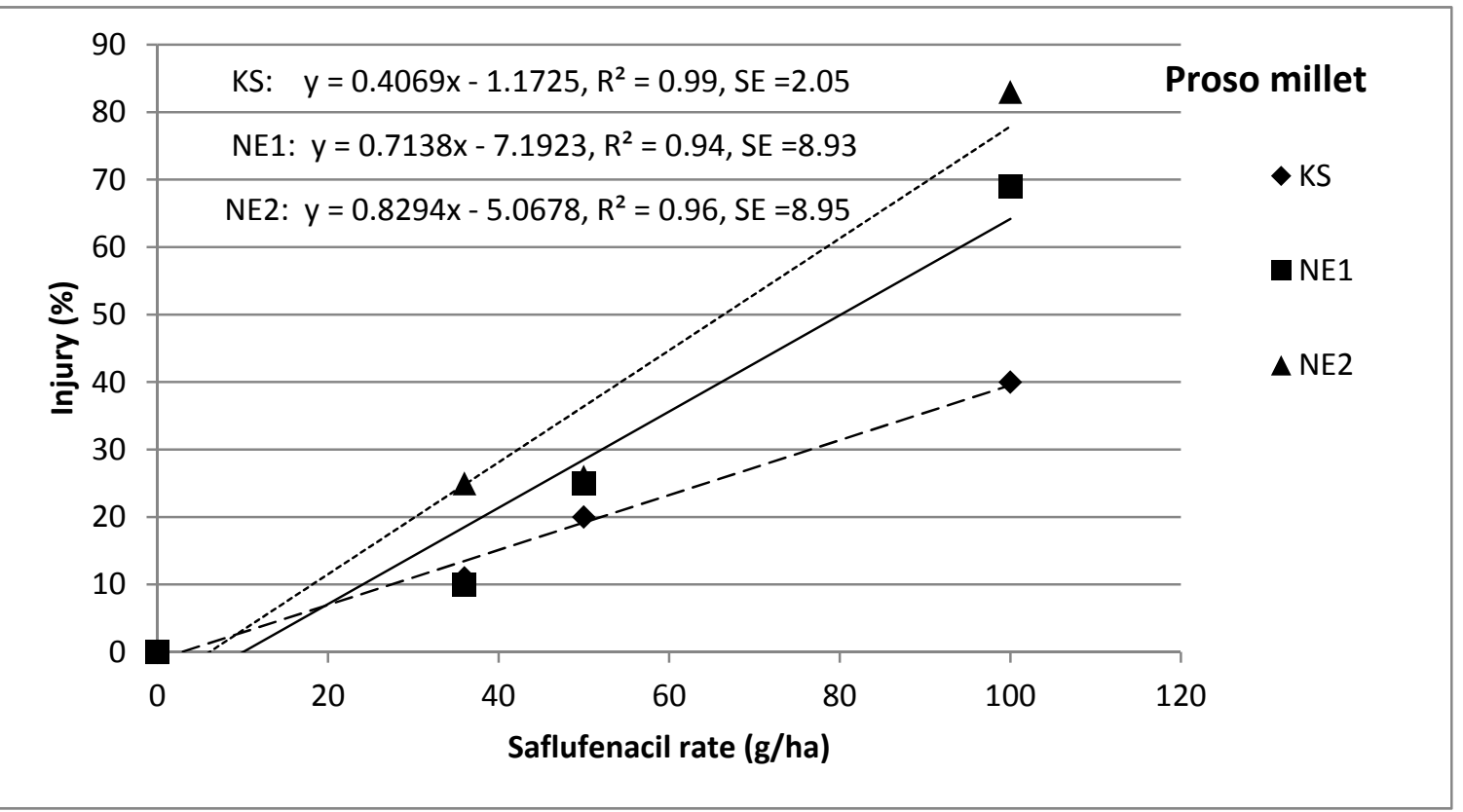

117

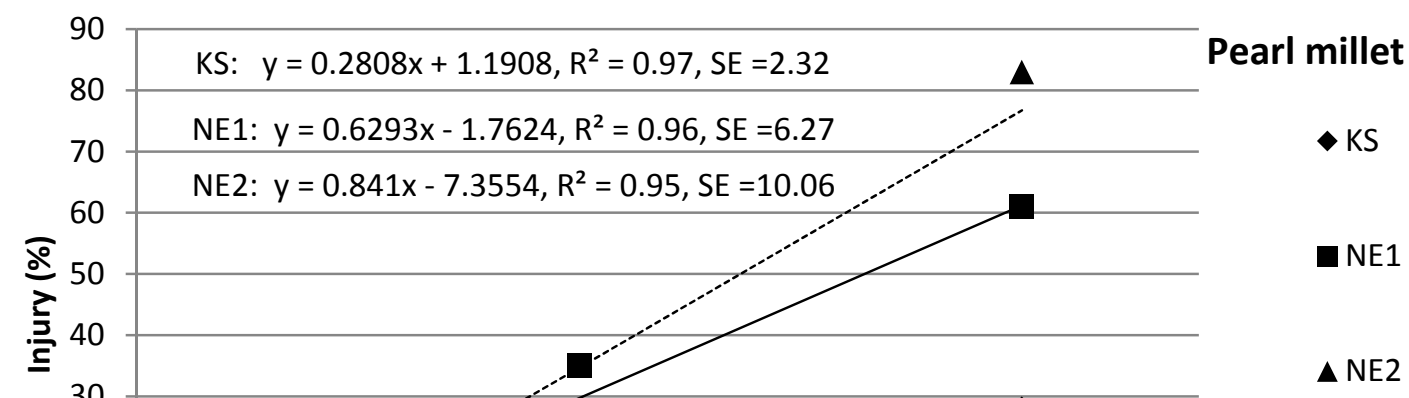

119 Fig 1. Proso and pearl millet injury regressed on saflufenacil rates applied PRE, 2009. KS = Hays, $120 \mathrm{KS} ; \mathrm{NE1}=$ Beaver crossing, NE; NE2, Scottsbluff, NE; $y=$ estimation of yield; $x$ = saflufenacil rate; $121 \mathrm{a}=$ intercept; $\mathrm{b}=$ slope; and $\mathrm{SE}=$ standard error of estimate. 


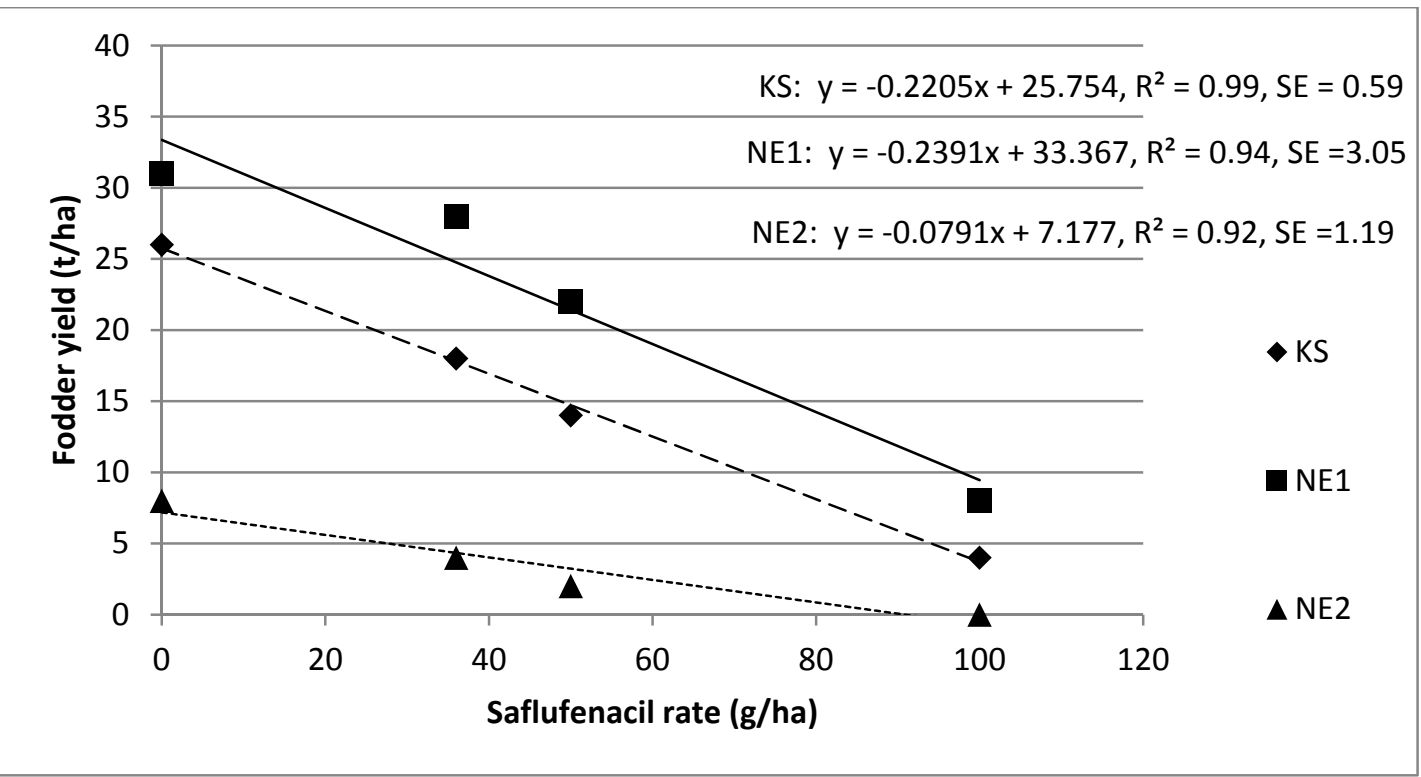

123

124 Fig 2. Foxtail millet fodder yields regressed on saflufenacil rates applied PRE, 2009. KS = Hays, $125 \mathrm{KS} ; \mathrm{NE1}=$ Beaver crossing, NE; NE2, Scottsbluff, NE; $y=$ estimation of yield; $x$ = saflufenacil rate; $126 \quad \mathrm{a}=$ intercept; $\mathrm{b}=$ slope; and $\mathrm{SE}=$ standard error of estimate. 